\title{
The Application of Contemporary Marketing Concept in the Sense of the Improvement of Business Subject Competitiveness
}

\author{
Snežana BEŠIĆ
}

\begin{abstract}
Modern business conditions and global markets require all business organizations to integrate modern management techniques into their organizational structure. Successful business cannot be based on obsolete techniques and management principles. Management of an organization must be in line with the users' needs and environment requirements. Due to the intensification of global competition, special attention should be paid to the application of modern marketing methods and techniques. This paper presents an overview of the research results related to the application of modern marketing methods and techniques with the aim of improving the competitiveness of a company.
\end{abstract}

Keywords: competitiveness; globalization; managing; marketing

\section{INTRODUCTION}

Modern business conditions, defined by the process of business globalization and modification of competitive relations, require the change of the existing management practice of a semi-public organization, especially from business practice perspective. A business organization cannot operate successfully unless it applies modern methods and techniques of management. Globally business, which takes on the character of doing business in conditions of market turbulence, requires making business decisions regarding realistic adjustment to the market situation.

In modern business, companies need a new way of thinking which involves abandoning dysfunctional methods and techniques of management and applying modern marketing methods and techniques. In modern global business, organizations must turn to innovating and creating new organizational postulates. A new understanding of marketing involves creating a new one. According to Kotler [1], new marketing has to deal with creating, communicating and delivering superior value to the target consumer group. Marketing is a generator of company growth.

Marketing has always been understood as the most important aspect for the success and growth of modern business organization. However, nowadays good marketing management is a prerequisite for achieving competitive advantage in the global market. Marketing creates the growth of a modern business organization, and marketing management, as well as connecting marketing with research and development and quality, is the basis for successful business.

A successful market performance on the global market is of particular importance for companies coming from countries in transition. Appearance on the global market is a basic assumption of the market development of enterprises from countries in transition. Enterprises coming from countries in transition are faced with competitors arriving not only from the EU, but also from the newly industrialized countries of the world.

Domestic enterprises are not competitive on the global market, and the reason for this is in the fact that domestic enterprises are insufficiently productive, resulting in higher sales prices, as well as inadequate product quality. The problem of the non-competitiveness of Serbian economy in the international framework is a problem that has been evident since the end of the eighties of the twentieth century and it became highly visible at the beginning of the transition in 2001. Negative effects of the global economic crisis have only further influenced the weakening of the competitiveness of domestic enterprises. The indicators of global competitiveness, published by the World Economic Forum, point to the fact that the domestic economy has been facing the problem of non-competitiveness for a decade now - the economy of the Republic of Serbia is lagging behind in the competitiveness of all the countries of the western Balkans except Bosnia and Herzegovina and the gray countries of South-East Europe. During 2017, Serbia improved its position of global competitiveness ( $78^{\text {th }}$ place in the world); the biggest problem with the domestic economy is still extremely low innovation level ( $95^{\text {th }}$ place in the world).

The issue of improving the marketing function in modern business, and especially in companies coming from countries in transition, comes down to the question of improving knowledge and productivity of knowledge. Although the biggest ongoing problem among all companies in transition countries is the chronic lack of financial capital, in the long run, this indicates the lack of knowledge.

\section{MODERN UNDERSTANDING OF MARKETING}

New business conditions also require a new approach to the process of managing modern organization. Management methods and techniques that are not effective must be replaced with new ones more efficient. Educating employees, especially managers, is gaining an increasingly important role. Marketing theory and practice is moving to new boundaries. New business conditions also require new approaches to marketing studies. Marketing has been changing over the past twenty years. These changes are conceptual, as well as organizational, and they have tackled every part of marketing practice.

Marketing is a business philosophy that deals with the market and doing business on the market. This means that marketing is essential for the market organization of the 
organization. Marketing is a business concept which is market-oriented. Marketing allows the company to gather information from the market, use it in business decisionmaking, form a business offer and place it on the market by paying considerable attention to the issue of customer satisfaction.

According to Draker [2], the essence of any organization is seen in marketing and innovation. The goal of marketing is to create sales super flows - to know and understand consumers so well that the products and services fully satisfy the needs and wishes of consumers and thus are sold on the market.

According to Kotler and Armstrong [3], it is a social and managerial process which enables individuals and groups to perceive their needs and desires through the creation and exchange of products and evaluations with other products. Marketing is a skill to create and gain value for the customer. It is a skill to help our customers get richer. The traits of each marketer are: quality, service and value.

Marketing begins by identifying the market demands. The ultimate goal of managing marketing is to achieve customer satisfaction, which is aimed at achieving customer loyalty. Customer satisfaction is the consumer's opinion on the degree of fulfillment of his expectations of the purchased product. According to Adižes [4], the success of any system, either micro or macro, it being one human being, family, organization or society, can be predicted by using one single factor - the relationship between external and internal marketing. Success is the function of marketing.

In modern business, companies need a new way of thinking, which involves abandoning dysfunctional methods and techniques of management and applying modern marketing methods and techniques.

According to Grubor [5], changes in marketing management are due to the influence of contemporary social factors and they have visible implications on the whole of the marketing program. Achieving competitive advantage requires marketing managers to think beyond the present, to think for consumers, and to think beyond the organizational parameters.

Nowadays, marketing is a function that has a strategic significance for doing business and, together with research and development and quality management, it defines a strategic framework business.

Enterprises have to turn to proactive thinking, which involves understanding and creating change, and step away from a traditional understanding, defined by a linear way of thinking where all business functions were of equal importance. This includes the restructuring of the business functions within an enterprise.

In the past, all functions were seen as equal and for a long time the advantage was given to production. Such a model has become outdated with the establishment of globalization and the development of new competitive relations. Hamel believes that reengineering, reducing costs, continuous improvement, outsourcing and offshoring are fully consistent with the genetic preferences of large companies [6]. Ultimately, this implies that for a modern business organization, it is essential to directly deal only with those business functions that are oriented towards the future, i.e. they have a strategic sign.
Modern operating conditions of company management emphasize the business functions that have a strategic trait due to their market orientation. Those are:

- Marketing,

- Quality and

- $\quad$ Research and development [7].

The growth and development of a company, and hence its success, is determined by the close interdependence between the three mentioned functions and their synergetic effect. Marketing has to recognize possible market chances and transform them into a new product that buyers will accept. Innovation begins and ends with marketing. By integrating innovation with quality, marketing achieves the definition of a stable market position and long-term growth. Marketing is not necessary merely as an additional effort to make some technological innovation market successful, but it is important in the entire process of technological innovation. Quality implies the quality of the organization's business. It is reflected on the basis of executive leadership. Quality is a management phenomenon and focuses on satisfying the requirements of the consumers. Quality implies the development of a certain quality management model in the organizational structure. Quality management should result in improved productivity and customer satisfaction. Marketing as a business function must perform both vertical and horizontal synchronization of the company's activities. Vertical synchronization implies harmonization of different levels of decision-making, while horizontal one implies the role of marketing in the coordination of different business functions in order to achieve a unique business goal.

One of the most significant achievements in marketing theory and practice in the mid-nineties of the twentieth century was the definition of marketing relations in conceptual, but also in practical terms.

According to Kotler et al. [8], the contemporary concept of marketing involves holistic marketing which consists of the following dimensions:

- Internal marketing,

- Marketing business results,

- Integral marketing and

- Marketing relationship.

Internal marketing implies relations between the marketing, management and other sectors within an enterprise. The marketing of business results is aimed at increasing sales revenues, increasing market value of the brand, ethics, community, business environment and the environment. Integrated marketing assumes relationships that arise in connection with communication, production, and services and channels. Finally, relationship marketing involves realities between partners, consumers and marketing channels. Relationship marketing implies a business practice model based on database management, interactive marketing and network marketing. Relationship marketing is also marketing that is correlated with the public interest and it includes the following principles: freedom of consumers and producers, restoring potential damage, meeting basic needs, economic efficiency, innovation, education and consumer information, and consumer protection. 
A company that wishes to maintain competitive ability in the long run has to pay considerable attention to changes in the environment. Modern market understanding in terms of realization of business operations on the market is completely different in relation to some previous periods. This is the result of the actions of social and economic forces (globalization, liberalization of economic relations, the importance of technology, global communication, etc.) that have led to the emergence of new consumers and new opportunities, as well as the company's abilities.

According to Kotler [9], it is evident that we are entering a new era of turbulence. Turbulence is a new normality. Turbulence affects the disappearance of stability in a particular environment, for example, nature or society. Stability disappears, and the possibility of forecasting the event becomes smaller. This means that, in the case of techno-economic turbulences, society becomes more and more exposed to the force that causes turbulence. The main cause of business turbulence in the modern economy is the complication of competition. Global competition is complex and intense, and the number of competitors is increasing every day. There is also competition not only between branches but also between branches and groups, as well as between different technological solutions.

Kotler suggests the application of the chaotic control system to avoid the significant impact of market turbulence. According to Kotler, the Haotika management system helps managers re-think the full approach to management and marketing during the recession and other turbulent conditions, among other things, how to develop an early warning system and identify the first signs of change, including devastating innovations and shocks; creating detailed the worst, best and most anticipated scenarios using strategies to deal with each of them; strategically cut costs or increase productivity; to provide a market share in the basic consumer segment; compress strategic planning into shorter, three-month cycles to help keep track of the company's pulse and prevent the potentially catastrophic consequences of abandoning basic principles.

Every day market and marketing practice show the direction in which marketing should go. Social media revolutionized the marketing world. Digital marketing and technology have transformed the way of doing business. In the digital economy, consumers are socially linked to each other on the basis of horizontal communication network. Consumers become aware of their needs, become more educated and more informed, and a networked computer is a consumer-owned medium. Electronic media based on information technology summarizes the time needed to transmit information. Customers are more informed than ever and they are able to find almost all information about any product, service or company by searching the Internet and contacting other people in social networks. Internet and social networks have created radically new media and sources of information, as well as new direct sales assets. They are more and more willing to buy trademarks and trust them even though their prices are lower than globallyknown brands, whose prices are higher. Competitors are able to copy each new product faster and thus reduce the return time of investment in innovation. The competitive advantage is in the modern economy of a significantly shorter life span. These changes also require the executives and marketing professionals to think in radically new ways.

Marketing experts need to take on a new reality in the marketplace and to create brands that act like humans. This means they are affordable and attractive.

According to Kotler [10], marketing experts need to shape brands to become authentic and honest, to accept their flow and to stop trying to look perfect. Kotler recognizes the new marketing model and introduces the term for modern marketing practice - Marketing 4.0, a marketing approach that combines direct and indirect interaction between companies and consumers. Kotler suggests that we do not abandon traditional marketing, but rather combine traditional and digital. Kotler believes that, in the final outcome, technological convergence leads to convergence between digital marketing and traditional market. The role of the marketers is to guide consumers through their journey from awareness to the ultimate degree of product representation. In today's hyper-linked marketing environment, consumers are moving from consciousness (I know about the product), towards acting (I buy a product) and representing (I recommend the product).

\section{ANALYSIS OF THE APPLICATION OF MARKETING IN DOMESTIC ENTERPRISES}

The competitive position of companies from countries in transition, and especially the countries of the Western Balkans, based on renown on the world market is unfavorable. This is a trend that has been observed over the last ten years. Companies from the countries in the market did not invest adequate marketing efforts in the formulation of the credit, as an element that influences the market position of a modern business organization, as well as competitive ability. Business organizations from countries in transition must also resort to a series of transformations leading to real market operations, such as organizational, technological and marketing transformation. Business organizations from countries in transition do their work with obsolete equipment, based on obsolete technologies, and there is a noticeable lack of knowledge. Generally speaking, domestic enterprises (those corporations dominated by domestic private capital) have problems with business efficiency, primarily due to poor management of the organization - management is based on overcoming postulates, which, with inadequate business quality and low productivity, results in poor competitive ability in international terms. Domestic companies are marginal and not competitive in the global market, so their internationalization of engagement is directed towards the region of the Western Balkans and the EU.

It is believed [11] that the inadequate application of modern methods and management techniques certainly contributed to poor competitiveness. The productivity problem did not arise in the domestic economy during the transition, but it was present even earlier. Problems in the productivity of domestic enterprises were the result of inadequate business practices that were not based on market principles. The result was the unrealistically high prices of certain products that could not pass on the world market. That is why domestic companies lowered prices for exports in order to successfully compete on the world 
business scene, and the difference in non-productivity was paid by domestic consumers through high prices. Outdated technology, poor quality, unattractive packaging and high prices are the main reasons why Serbian products cannot match other competitive products in the international market.

According to some perceptions [12], the noncompetitiveness of products and services from Serbia on the world market is reflected in the low degree of coverage of imports by export of products that are technologically intensive. Most of the products exported by Serbia have no technological content or quality that is competitive on the international market, which has led to a small export of these products and low income from technology exports. Serbia therefore lags behind the applied technology for developed countries and is largely dependent on foreign countries.

The development of marketing theory and practice in domestic market did not run in a balanced way. While marketing as a theory began to actively develop from the early 1980s of the twentieth century, marketing practice was delayed by the development of theory. Marketing began to appear as a practice only with the beginning of a transition in the early 1990 s, when marketing agencies that were part of the international marketing chains started to operate on the domestic market. This has influenced the development of the application of modern methods and techniques in the domain of market communication. However, the integral marketing was not possible until the beginning of the nineties, when economic reforms began and when foreign companies came to the domestic market that invested in domestic business systems.

According to Đorđević et al. [13], the problem of domestic enterprises at the beginning of 2000 , in relation to the application of marketing could be described in the following way:

- Inadequate acceptance of the marketing concept and the location of marketing,

- Disagreeing with the global marketing concept,

- Failure to accept market business in practice.

The privatization of domestic social enterprises after 2001 and the investment of foreign companies in the domestic economy have influenced the fact that in these companies, marketing practice is developing faster, some in domestic companies dominated by autochthonous private capital.

However, after 2001 the majority of domestic companies, especially those that were socially owned, were devastated - enterprises were engaged on an extremely poor technical and technological basis, which had a low cost and very low productivity, the management applied obsolete methods and management techniques. In such circumstances, marketing was not planned in advance and most of the marketing activities were reduced to promotion, primarily economic propaganda and sales promotion.

According to Djordjevic et al. [14], the largest number of domestic executives equaled marketing and promotion, and some of them went a step further and equaled marketing with sales. These are typical mistakes that are not only present in a domestic economy of transitional character. A misunderstanding of marketing is a typical phenomenon for countries in transition without a free market. Misunderstanding of marketing logic as a business concept and especially as a business function leads to the next problem - personalization of marketing by the director. Namely, CEOs believe they know best how to implement marketing function. The next wrong step is the wrong choice of people working in marketing - for example, in small and medium-sized businesses, it is common for cousins to conduct marketing events regardless of qualifications and this similarly happens in public enterprises.

The problem is obvious in the perception, that is, in the wrong perception of the reality of modern business, which is the result of several decades of lagging behind the domestic economy. With a significant role of international companies in the domestic market, this has partially been changed. In companies where the ownership structure was changed - privatized by foreign companies, marketing began to be actively applied as a psychic practice, taking into account modern methods and techniques of marketing. On the other hand, in the domestic small and medium-sized enterprises, which dominate the total number of enterprises in the domestic market, as well as public companies, which dominate the aspect of fixed capital, there are no outperforming results in this field.

According to some researches [15] that dealt with the role of modern methods and management strategies in the domestic market, the most important techniques to be applied in domestic enterprises, in order to improve the efficiency of operations towards the more mature managers of domestic enterprises are: database management (18.4\%), quality management system $(17.6 \%)$, corporate social responsibility $(17.6 \%)$, marketing relations $(16.8 \%)$ and benchmarking $(12.6 \%)$.

\section{THE RESEARCH METHODOLOGY}

The presented results represent a part of a broader survey of managers' positions in domestic companies in relation to marketing attributes that determine the competitiveness of the company. This research was conducted in the period from December 2017 to April 2018 on the territory of the Republic of Serbia, in order to obtain the opinion of the company's managers on the possibilities for creating a new model of practice which is based on the application of modern methods and techniques of marketing management in order to improve the efficiency of operations and competitiveness. The basic research instrument was an expert questionnaire that was realized as immediate and structured tool and its role was to enable relevant attitudes from the analyzed area to be obtained.

The questionnaire has been designed to include issues of business improvement, implementation of marketing concepts in domestic companies, the application of modern methods and techniques in the field of market in domestic companies and recommendations for improving the organization of business entities in the new operating conditions. The survey sample was designed to a size of 250 units (company executives), but in the data base it is operated with 249 units. Within the broader scope of the research, the hypothesis is that domestic enterprises are not sufficiently applying modern methods and techniques of 
marketing, which results in poor competitive ability in the international frameworks.

Exploring of marketing activities was performed by analysis of results of a survey conducted in 249 organizations. Managers, who are experts in the field of marketing, based on their familiarity with the wide range of various business activities in their firms, gave answers to questions in the presented questionnaire. Out of 249 organizations, $126(50.6 \%)$ are private properties, 109 $(43.8 \%)$ firms are state owned, and the rest of $14(5.6 \%)$ are in mixed ownership. The number of employees is distributed in the following way: up to 10 employees are in $26(10.4 \%)$ organizations, 11 to 50 in $41(16.5 \%), 51$ to 250 in $57(22.9 \%)$ and over 250 workers are employed in 125 $(50.4 \%)$ of surveyed organizations.

We set two main tasks of investigations in our work: first, to learn about the main goals of marketing activities in the surveyed companies, and second, to reveal the most frequent central marketing activities. In our analyses, we will employ methods of descriptive and inferential statistics; the internal consistency of the survey, observed through the mutual accordance of answers given for the two groups of questions, will be tested using Cronbach's alpha coefficient.

\section{RESULTS AND DISCUSSION}

For the first part of our exploration work, the next questionnaire was given to the participants: Please select the most important goal(s) of marketing activities in your organization:

1 Business excellence achievement

2 Permanent promotion of business quality

3 Development of competition ability

4 Obtaining of values for customers

5 Access the global market.

The majority of respondents (231) only chose one answer, and the others quoted two to three answers. The permanent promotion of business quality was the most frequent choice $(38 \%)$ of all answers, after that follow obtaining values for customers, development of competitive ability and business excellence achievement; marketing activities performed to access the global market are relatively rare (7\% of all answers). In Fig. 1 the distribution of relative frequencies is shown for marketing activities performed in the surveyed organizations.

Calculated $95 \%$ confidence interval of the percentage of the marketing task "Permanent promotion of business quality", as the most frequently used activity, amounts to $32.33 \%-44.23 \%$; as our sample is representative for the Serbian firms, it comes out that at least around every third of all organizations in our country apply marketing activities to improve their business quality. The next most important goal is to obtain values for customers, with $95 \%$ confidence interval $16.73 \%-26.86 \%$; it follows that at least every sixth organization in Serbia as the main task of their business takes forming value for customers. These conclusions only are related to one chosen goal through the questionnaire, but one has to take into account that business quality, values for customers, competitive ability and business excellence are also contained within as marketing goals in every organization, just in diverse orders.

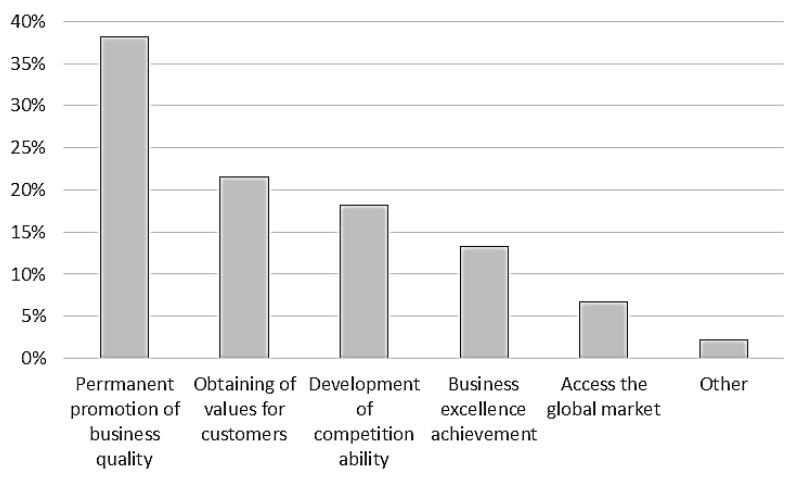

Figure 1 Distribution of ordered relative frequencies of main goals of marketing activities

As in our survey only 14 firms participated with mixed ownership, they are not included into the next comparative analysis. In Fig. 2, distribution of frequencies of main goals of marketing activities in private and state owned organization is given. In state owned firms as many as $46.61 \%$ responses were related to the marketing goal "Permanent promotion of business quality" and at the second place is "Obtaining values for customers" with proportion of $22.88 \%$. At privately owned organizations, permanent promotion of business quality is also at the first place, but with less frequency, amounting to $30.43 \%$ and the next in the queue is "Development of competitive ability" with $25.36 \%$. In the next figure, relative distribution of frequencies of marketing goals is given for firms as state properties and privately owned ones.

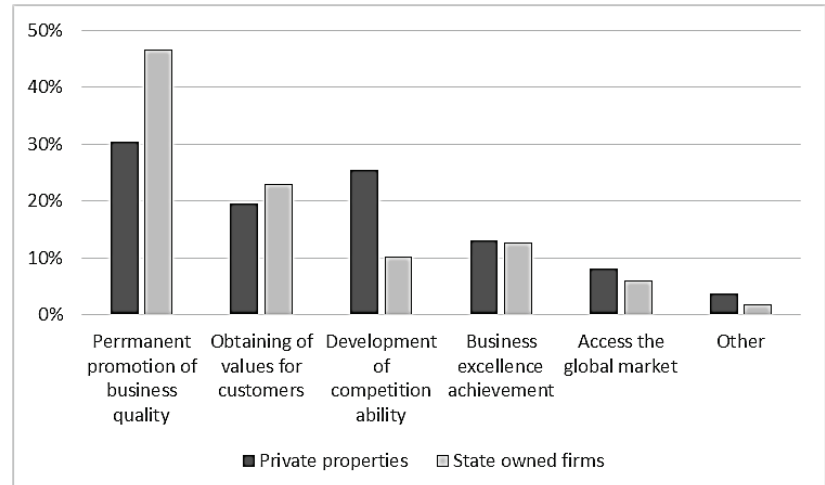

Figure 2 Distribution of relative frequencies of main goals of marketing activities in private organizations and state owned firms

We will perform testing of differences between proportions applying the Chi-squared test, with n-1 degrees of freedom. The results show that the presence of the marketing goal "Permanent promotion of business quality" is statistically significantly more frequent (the difference between proportions is 16.18 points) in state owned organizations than in private properties $\left(\chi^{2}=7.049\right.$, $p=0.0079)$. The difference between proportions for the marketing goal "Development of competition ability" is 15.19 points in favor of private organizations; these firms statistically highly significantly more frequently involve this goal compared to state owned organizations $\left(\chi^{2}=9.754\right.$, $p=0.0018)$. The remaining marketing goals are similarly present in both types of organizations, without statistically significant differences. 
In Fig. 3, the distribution of marketing goals formulated in organizations sorted by the number of employees is presented.

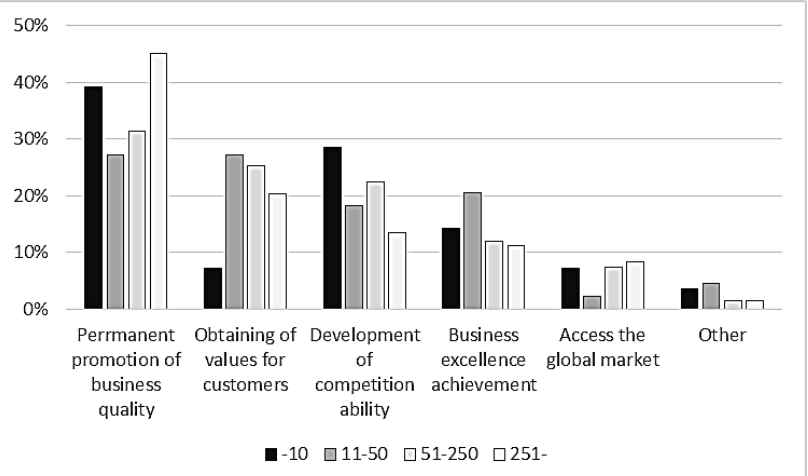

Figure 3 Distribution of relative frequencies of main goals of marketing activities in organizations sorted by the number of employees

Permanent promotion of business quality is the first order goal of marketing activities in all firms, independent of their size. There are substantial differences between smaller and greater organizations concerning other goals. The smallest firms strongly tend to develop their competition ability, more than others do and they put weak emphasis on obtaining of values for customers, much less than bigger firms. Test of the difference between proportions gave results as follows. Obtaining of values for customers is present only with $7.14 \%$ of the smallest firms, while in greater ones it is quoted $22.95 \%$ in average, test value for difference between proportions is $\chi^{2}=3.729$, significance level $p=0.0535$, meaning there is a stronger tendency of avoiding this goal in smaller than in greater firms. Development of competition ability is set as marketing goal in $28.57 \%$ of smaller firms, and in $16.80 \%$ in the greater ones in average, although statistically the difference is not significant, $\chi^{2}=2.348$, significance level $p=0.1255$. Permanent promotion of business quality is more emphasized as marketing goal in the companies with the utmost number of employees (over 250). Here the proportion of this goal prevails others and amounts to $45.11 \%$. The same goal is present in companies with 11-50 employees in $27.27 \%$, the difference between proportions is statistically significant, $\chi^{2}=4.336$, significance level $p=0.0373$. In firms with employees $51-250$ the proportion of this goal is $31.34 \%$, and there is a statistical tendency that the greatest firms prevails, $\chi^{2}=3.488$, significance level $p=0.0618$. As for defining other marketing goals, we did not establish any significant differences between firms of different sizes.

After investigating the main goals of marketing activities in the surveyed firms, our attention was payed to the very marketing activities each firm uses in their business as to achieve the specified goals. To take insight into this problem, the next questionnaire was given to the respondents: Please indicate the most frequent marketing activities in your organization (select up to three answers)

1 Interactive marketing communication

2 Analysis of customer satisfaction

3 Direct marketing

4 Network marketing

5 Customer relationship management

6 Branding
7 Lateral marketing

8 Advertising

9 Sales promotion

10 Public relations

11 Corporate social responsibility.

Out of 249 respondents, 203 selected three answers, 38 of them two answers and 8 experts indicated that their company only uses one type of marketing activity. In the next figure, frequencies of marketing activities in surveyed companies are shown in decreasing order.

As shown in the graphical presentation the most frequent marketing activities are Analysis of customer satisfaction and Sales promotion. These activities were quoted 117 and 114 times, respectively. The next activities were applied in relatively similar frequencies (from 77 to 53), and the last two, Network marketing and Lateral marketing, have sporadic application (only mentioned 15 and 10 times, respectively).

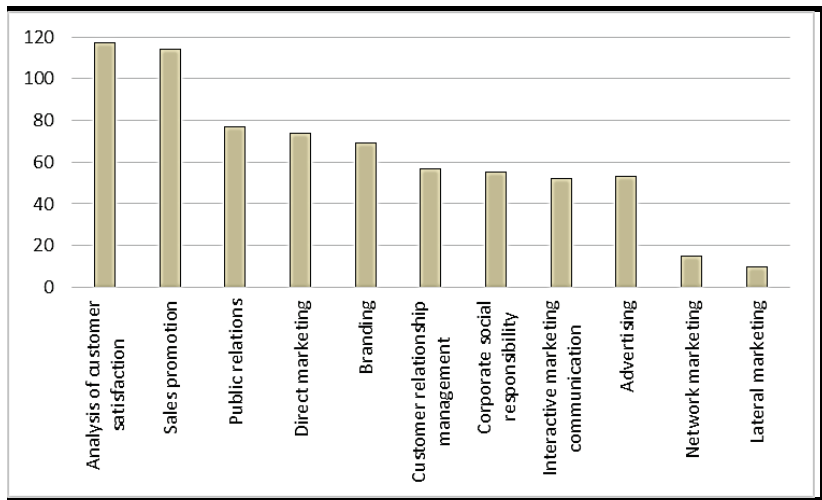

Figure 4 Distribution of frequencies of marketing activities in surveyed organizations

Since there are eleven types of marketing activities quoted, it comes out that there are 55 different combinations of a pair of possible activities chosen together. While of 249 organizations in 117 analyses of Customer satisfaction is used, and in 114 Sales promotions is one of main marketing activities, in 57 cases these activities are applied jointly in the same organizations and this is the most frequent pair of activities. The following often-used pairs are: Analysis of customer satisfaction + Direct marketing (28 cases), Analysis of customer satisfaction + Public relations ( 28 cases), Branding + Sales promotion (28 cases) and direct marketing + Sales promotion ( 27 cases).

In Fig. 5, the distribution of relative frequencies of marketing activities in private organizations and state owned firms is presented. Direct marketing and Branding are statistically more frequently used in privately owned firms than in state owned ones (tests of differences gives $\chi^{2}=6.928, \quad p=0.0085 \quad$ and $\chi^{2}=10.644, \quad p=0.0011$, respectively). On the contrary, Public relations and Corporate social responsibility as marketing activities prevail in state owned organizations (tests of differences gives $\chi^{2}=8.545, \quad p=0.0035$ and $\chi^{2}=6.719, p=0.0095$, respectively). Frequencies of use of other marketing activities do not differ significantly between private and state organizations. Of special interest is the fact that both in private and state owned organizations Analysis of 
customer satisfaction and Sales promotion belong to top marketing activities.

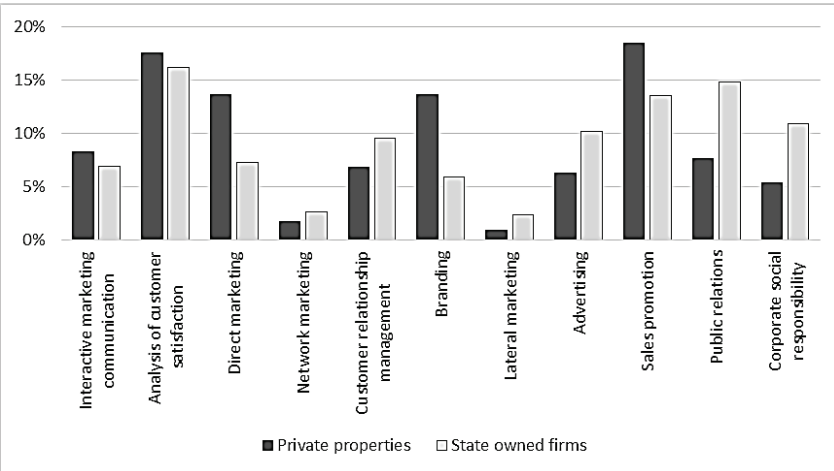

Figure 5 Distribution of relative frequencies of marketing activities in private organizations and state owned firms

When observing marketing activities applied in surveyed organizations dependent on the number of employees, various patterns appear with several characteristic tendencies, as shown in Fig. 6. Direct marketing and Sales promotion are more often used marketing activities in smaller firms, and the frequency declines with the growth of the number of employees. This also applies to the rarely used network marketing as well. On the contrary, the greater the firm the higher is the frequency of using Public relations and corporate social responsibility. Besides that, the small number of applied Lateral marketing is present almost only in state owned firms.

-10 ㄴ11-50 ㅁ51-250 251-

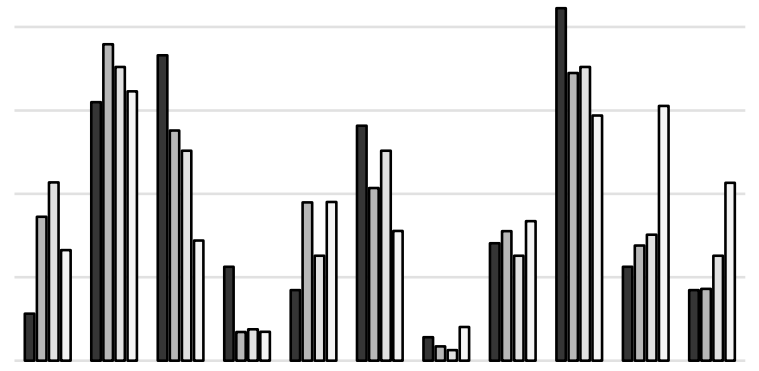

Figure 6 Distribution of relative frequencies of marketing activities in organizations sorted by the number of employees

To analyze the consistency of the survey, we compared answers from the first group of answers, which were related to main goals of marketing activities, with answers from the second group, where the most frequent marketing activities were chosen. At first, we took firms in which Obtaining values for customers was the main goal of marketing activities and checked whether these firms apply marketing activities Analysis of customer satisfaction and Customer relations management. We calculated Cronbach's alpha coefficient on data transformed to binary numbers (used activity $=1$, not used $=0$ ) and got the result $\alpha=0.934$, since out of 47 organizations which declared values for customers as main goal, 38 regularly apply either one or both corresponding marketing activity. Since alpha is greater than 0.9 , we may conclude the internal consistency of the survey. The second control is related to main goal Development of competition ability and the application of one or more of marketing activities Branding, Advertising and Sales promotion. Here, forty firms declared the mentioned main goal, and 31 of them applied one, two or three of these activities. Test result is $\alpha=0.923$ and we may conclude the internal consistency of the survey is excellent.

\section{IMPROVEMENT AND RECOMMENDATIONS}

Management methods and techniques identified by domestic enterprises managers as significant for business performance of their enterprises are all based on knowledge. New management paradigm at global level is based on the process of knowledge productivity improvement.

Leaders of domestic enterprises are aware of the fact that the application of modern methods and management techniques, such as integrated management systems, in the function of improving the quality of operations, satisfaction of the customers and competitiveness is necessary. The application of classic marketing techniques is more prevalent than the application of modern techniques, such as network marketing or lateral marketing. The following general recommendations for improving marketing activities of domestic enterprises are distinguished:

- Necessity for permanent knowledge innovation of all employees, predominantly marketing experts, who should be taught the most advanced world experiences and modern methods and techniques of marketing management,

- Necessity of planning the approach to marketing activities,

- Necessity of permanent quality improvement, organization functioning and management innovativeness are imperatives of business performance in modern society.

There are three ways of increasing enterprise's creativity:

- Employment of naturally creative people, who would be given freedom in their work,

- Creativity stimulation by means of using a great number of well tested methods, and

- Engagement of external experts who would enable the appearance of new interesting ideas [16].

Marketing ought to be clearly positioned within internal environment of business functions in the enterprise as a function of strategic significance, together with research and development function and quality management function. The stress is on wider acceptance of a new marketing model, characterized by technological development and represented in marketing communication component through the model of integrated marketing communication. Innovations, flexibility and productivity are guidelines for the future development in the field of competitiveness and organizational management. The very essence of the struggle for competitiveness lies in accepting changes. The future belongs to those business organizations that are the most resourceful, innovative and flexible. 


\section{CONCLUSION}

Global markets and modern business conditions require from companies to change their business philosophy and ways of behavior in their business practice. New marketing model signifies a considerable advance in marketing approach, going from thinking exclusively about competition and conflict categories towards the categories of collaboration and interdependence. The application of modern management techniques is an essential precondition for the success of business in general. Wrong understanding of marketing is typical for transitional countries and developing countries without free markets. To achieve commercial success of the company it needs to have a competitive advantage in the form of lower costs and/or product differentiation, with a long-term strategy of providing products and services of high quality and continuous innovation. Serbian companies have to use global experiences, standards and globally acknowledged business practice in the process of their business internalization. It is therefore necessary to implement these management techniques that potentiate long-term commitment towards competitiveness, such as marketing, quality management, benchmarking, etc.

\section{REFERENCES}

[1] The future of marketing according to Philip Kotler. NEC, February 2018. www.wisdom.nec.com (07.05.2018)

[2] Drucker, P. (2003). Moj pogled na menadžment, Asee Books, Novi Sad. (in Serbian)

[3] Kotler, P. \& Armstrong, G. (1996). Principles of Marketing, Prentice-Hall International, Inc, Englewood Cliffs.

[4] Adižes, I. (2006). Upravljanje promenama, Asee Books, Novi Sad. (in Serbian)

[5] Grubor, A. (2012). Marketing menadžment u funkciji razvoja novog privatnog sektora. Poslovna ekonomija, 6(1), 79-90. (in Serbian)

[6] Hamel, G. (2009). Budućnost menadžmenta, Asee Books, Novi Sad. (in Serbian)

[7] Đorđević D. \& Ćoćkalo D. (2010). Osnove marketinga, Tehnički fakultet Mihajlo Pupin, Zrenjanin. (in Serbian)

[8] Kotler, P., Keller, K. L., \& Martinović, M. (2014). Upravljanje marketingom, Mate, Zagreb. (in Croatian)

[9] Kotler, P. \& Caslione, J. (2009). Kaotika, Mate, Zagreb. (in Croatian)

[10] Kotler, P., Kartajaya H., \& Setiawan, I. (2017). Marketing 4.0, John Wiley and Sons Inc, Hoboken, New Jersey.

[11] Đorđević, D., Ćoćkalo, D., Bešić, C., \& Bogetić, S. (2018). The role of quality in process of improving competitivness of domestic economy. International Journal of Advance Quality, 46(1), 21-26. https://doi.org/10.25137//JAQ.n1.v46.y2018.p21-26

[12] Stanković, Lj. \& Popović, A. (2016). Veličina tržišta kao determninanta nacionalne konkuretnosti Republike Srbije. Marketing, 47(3), 191-204. (in Serbian)

[13] Đorđević, D., Anđelković, M., \& Bogetić, S. (2001). Restrukturiranje domaćih preduzeća, KAS, Beograd. (in Serbian)

[14] Đorđević, D., Ćoćkalo, D., \& Bogetić, S. (2016). The analysis of marketing concept implementation in domestc enterprises. JEMC, 6(2), 120-128. https://doi.org/10.5937/jemc1602120D

[15] Bešić, C., Krnjević-Mišković, Z., \& Đorđević, D. (2013). The Role of Knowledge in the Development Process of Competitive Ability of Domestic Companies on the Global
Market. International Journal of Economics \& Law, 3(7), 17.

[16] Kotler, P. (2004). Marketing Insights from A to Z, Asee Books, Novi Sad. (in Serbian)

[17] Masaki, I. (2008). Kaizen, Mono i manjana, Beograd. (in Serbian)

Contact information:

Snežana BEŠıć, MSc

High railway school of professional studies,

Zdravka Čelara 14, 11000 Beograd, Serbia

E-mail1: snezana.besic63@gmail.com

E-mail2: snezana.besic@vzs.edu.rs 